\title{
Editorial: Camel Milk as a Therapeutic Food: A Postmodern SciTech
}

\author{
Akbar Nikkhah*
}

Chief Highly Distinguished Professor, Department of Animal Sciences, Faculty of Agricultural Sciences, University of Zanjan, Zanjan 313-45195, National Elite Foundation, Iran

The objective of this editorial article is to describe camel milk as a postmodern novel therapeutic dairy food in supporting healthy and functional human life in the new times. Camel milk has on average $11.7 \%$ total solids, $3.0 \%$ protein, $3.6 \%$ fat, $0.8 \%$ ash, $4.4 \%$ lactose, and a $\mathrm{pH}$ of 6.5 . The levels of $\mathrm{Na}, \mathrm{K}, \mathrm{Zn}, \mathrm{Fe}, \mathrm{Cu}, \mathrm{Mn}$, niacin and vitamin- $\mathrm{C}$ are greater and that of thiamin, riboflavin, folacin, vitamin $B_{12}$, pantothenic acid, vitamin-A, lysine and tryptophan are relatively lower compared to cow milk. Milk fat has a molar \% of 26.7 palmitic acid, 25.5 oleic acid, 11.4 myristic acid, and 11.0 palmitoleic acid [1-4]. Camel milk is more similar to goat milk and contains less short-chain fatty acids than cow, sheep and buffalo milk. In vitro protein digestibility and protein efficiency ratio values were $81.4 \%$ and 2.69 , respectively, based on $90.0 \%$ and 2.50 for ANRC-Casein. Camel milk contains substantially less vitamins-A ( $0.10 \mathrm{vs} .0 .27 \mathrm{mg} / \mathrm{L})$ and $\mathrm{B}_{2}$ ( 0.57 vs. $\left.1.56 \mathrm{mg} / \mathrm{L}\right)$, similar vitamin-E content $(0.56$ vs. $0.60 \mathrm{mg} / \mathrm{L})$, and about 3 times greater vitamin-C (37.4 vs. $11.0 \mathrm{mg} / \mathrm{L}$ ) than cow milk, respectively $[5,6]$.

Camel is known as the gold goal pseudo-ruminant of the 21st century in arid regions and dry lands. In Kazakhstan, $37 \%$ of the total milk is produced by camel, with sheep, yak and cows producing 30\%, 23\% and $10 \%$, respectively. Camel milk production varies from 3.5 up to $40 \mathrm{~L}$ per day under intensive management. Lactation lasts between 9-18 months, with peak yield occurring during the first 2-3 months postpartum. The range of major contents of camel milk were: fat $2.9-5.5 \%$, protein $2.5-4.5 \%$, lactose $2.9-5.8 \%$, ash $0.35-0.95 \%$, water $86.3-88.5 \%$ and solids-non-fat $8.9-14.3 \%$, with a mean specific gravity of $1.03[7,8]$.

Camel milk is receiving more approval as a global product in optimizing human health. The FAO predicts the camel dairy products will be on European

*Address correspondence to this author at the Chief Highly Distinguished Professor, Department of Animal Sciences, Faculty of Agricultural Sciences, University of Zanjan, Zanjan 313-45195, National Elite Foundation, Iran; Tel: 0098-24-33052801; Fax: 0098-24-33053202;

E-mails: anikkha@yahoo.com,nikkhah@znu.ac.ir supermarket shelves [1]. However, logistic challenges in manufacturing and processing must be overcome. Despite the increasing demands from Sahara to Mongolia, the annual 5.4 million tones camel dairy products are greatly inadequate. Sector and local investments must escalate to meet demands and create profitable markets both in the Middle East and the Western world. There are about 300 million potential customers in the Middle East and millions more in Africa, Europe and the Americas for camel dairy products. Although somewhat saltier than cow milk, camel milk represents a cost-effective husbandry under toughest conditions. In many regions of Iran, Russia, Kazakhstan and India, camel milk has traditionally been prescribed as a food treatment for multiple diseases recovery. Oral camel milk administration is protective against cadmium induced toxicity in rats. Camel milk is also known for its rich iron, unsaturated fatty acids and B-vitamins $[5,6]$.

In several regions of Iran, Pakistan and India, camel milk has long been used therapeutically against dropsy, Jaundice, spleen and liver complexities, tuberculosis, asthma, anemia, and piles. Camel milk is healthier when it is drunk as a cool drink. The milk also apparently has slimming properties. The belief by the Bedouin of the Sinai Peninsula exists that any internal disease can be cured by drinking camel milk through driving from the body all the bacteria. Such milk properties must additionally be attributed to what camel eats. By the rule of thumb considerations, generally camel milk nutritional value would be considered the lowest following milk from ewe, goat and cow. However, $4-5 \mathrm{~kg}$ of camel milk and milk products are sufficient to meet energy, lipids, proteins and calcium requirements of a man. The high proteins and amino acid proportions of camel milk casein make camel milk an appropriate food supplement for humans. The unfavorable odor and taste, however, could affect its popularity. Thus, it is recommended to purify the camel industrial casein to maintain its competitive status in the human health markets $[4,5]$. 

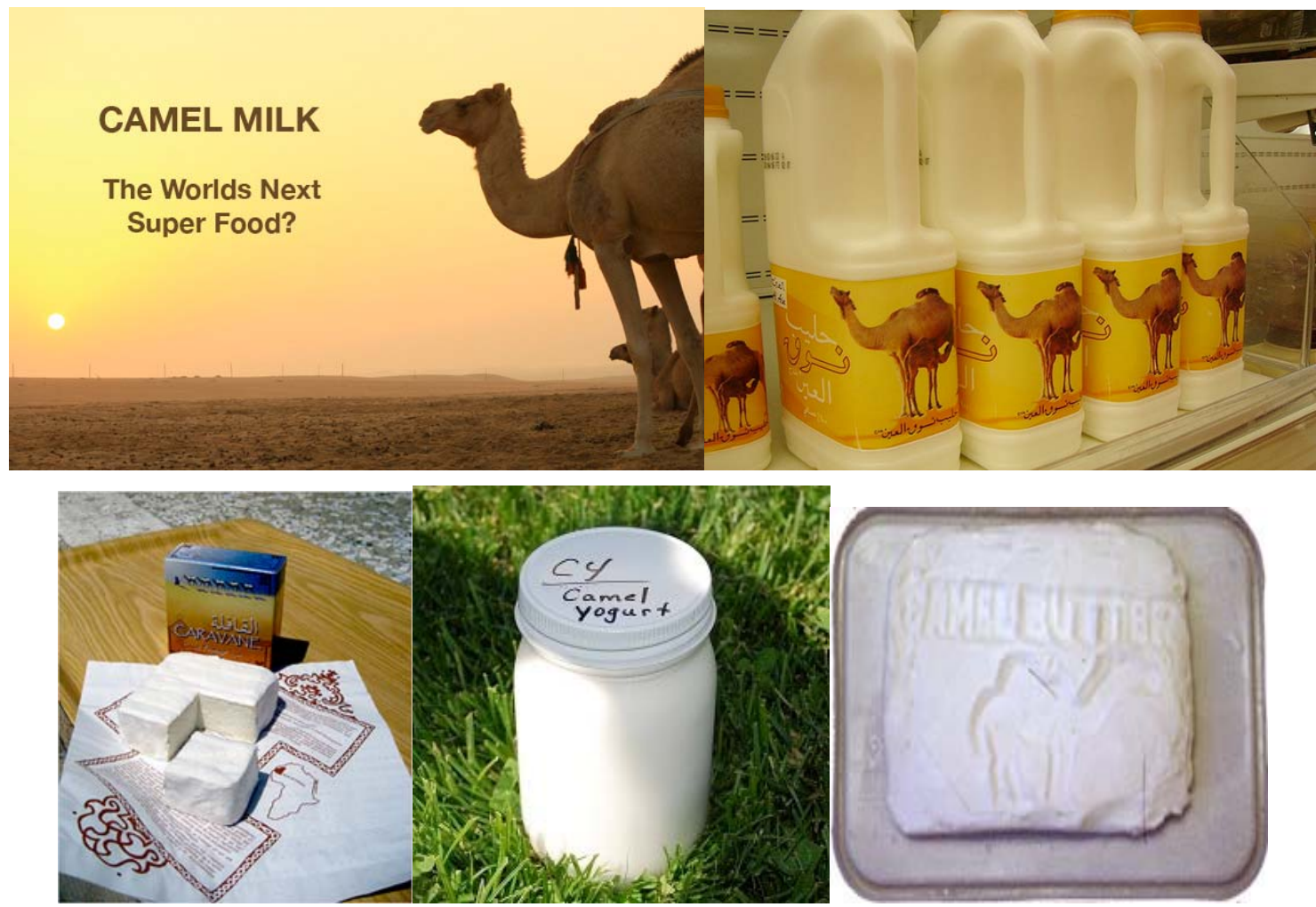

Figure 1: Camel dairy products: an educational prospect to serve functional human nutrition and health in the new era.

Camel milk lacks B-lactoglobulin and is rich in immunoglobulins, thus being compatible with human milk. More research is needed to further characterize biophysical and biochemical properties of camel milk as a SciTech functional replacement for cow milk and other dairy and animal products. Persistent education must be an obligation for such health implications to be adequately understood by global science and public communities (Figure 1).

\section{ACKNOWLEDGEMENTS}

The Ministry of Science Research and Technology, National Elite Foundation, and University of Zanjan, Iran, are acknowledged for supporting the author's global programs of optimizing the new millennium science edification.

\section{REFERENCES}

[1] Food and Agriculture Organization of the United Nation (FAO) 2005. Food and Agriculture Organization of the United Nations. FAOSTAT Data. http://faostat.fao.org.
[2] Khan BB, lqbal A. Production and composition of camel milk: Review. Pak J Agric Sci 2011; 38: 3-4.

[3] Merin U, Bernstein SD, Bloch-Damti N, Yagil R, van Creveld C, Lindner PA. Comparative study of milk proteins in camel (Camelus dromedarius) and bovine colostrums. Livest Prod Sci 2001; 67: 297-301. http://dx.doi.org/10.1016/S0301-6226(00)00198-6

[4] Nikkhah A. Camel Milk Science: State-Of-The-Arts. The First National Conference of Development of Camel Husbandry in Iran. University of Gonbad-E-Kavoos, Golestan, Iran 2014a.

[5] Nikkhah A. Milk of Camel and Yak: Time to Drink Education Worldwide. BLOG Scientific Research Publishing 2014. http://blog.scirp.org/biomedical-life-sciences/fns-biomedicallife-sciences/milk-of-camel-and-yak/\#.U_mV2aO5-_I

[6] Nikkhah A. Ruminant milk and human wellbeing: a multispecies review. In Milk Production. Rekik B, Ed. Nova Science Publishers, Inc., NY, USA 2012a; pp. 21-36.

[7] Nikkhah A. Science and Pseudo Science of Milk Intake and Human Health. In Milk Production. Rekik B, Ed. NOVA Science Publishers, Inc., NY, USA 2011b; pp. 15-20.

[8] Tsetsegmaa Ch, Altaibayar D, Dolgorsuren P, Munh-Erdene G, Erdenebileg U. Camel Milk Value Chain Assessment Report. Swiss Agency for Development and Cooperation (SDC) 2008. 